\title{
Technical efficiency of cocoa farming in Gorontalo Province
}

\author{
Ari Abdul Rouf ${ }^{1, *}$,Erna Retnawati $^{1}$, Dwi Rohmadi $^{1}$, Soimah Munawaroh ${ }^{1}$ and Awaludin \\ Hipi $^{1}$ \\ ${ }^{1}$ Gorontalo Assessment Institute for Agricultural Technology, IAARD, Ministry of Agriculture, \\ Iloheluma Gorontalo 96183
}

\begin{abstract}
Cocoa is an export oriented strategic plantation commodity that contributes to foreign exchange in Indonesia. It is mostly planted in Sulawesi Island, therefore, serves as a source of income for farmers. The purpose of this study was to analyze the efficiency of cocoa farming in Pohuwato Regency, Gorontalo. A total of 55 respondents were selected by simple random sampling. Furthermore, the Cobb Douglas stochastic frontier production function was used to analyze technical production efficiency and factors affecting it. Cocoa farming can be categorized as profitable, as the farmer reached average profit IDR 6,312,679/ha/year. However, in general cocoa farmers have not yet technically efficient because their technical efficiency value was only 0.52 . The cocoa production efficiency was positively and significantly affected by land area, fertilizer, pesticides and labor. The increase in farmer age causes a positive and significant rise in inefficiency. Conversely, education and the number of family members have a negative effect, although not significant. Therefore, it requires to increase cocoa farming efficiency by increasing farmers' access to production inputs such as fertilizers and pesticides, and improving the management of cocoa cultivation.
\end{abstract}

\section{Introduction}

Cocoa is an important plantation product in Indonesia and an export commodity that provides foreign exchange. From 2014-2018, export volume increased from 333,680 to 380,830 tons with a value of USD 1,245.80 million [1]. This is in line with the trend of cocoa production over the past two decades, which experienced a growth rate of 3.6 percent, with 421,142 tons in the year 2000 increasing to 737,483 in 2020 [1]. This shows that $97.29 \%$ of Indonesian cocoa is produced by small-scale plantations [2] with farmers' involvement by 1,370 million households [3].

Sulawesi Island is the center of cocoa production with a plantation area of $58.5 \%$ or 925,645 ha [1] and Gorontalo is one of the contributors with 4,213 tons produced in 2020 [1]. This number increased compared to 2012 production which reached 3,705 tons [4]. However, due to the level of productivity, the output rate of Gorontalo decreased from 877 in 2012 to $747 \mathrm{~kg} / \mathrm{ha} /$ year in 2020 [1, 4]. Previous studies [5,6] concluded that the low

\footnotetext{
* Corresponding author: ariabdrouf@gmail.com
} 
productivity is due to pests and diseases such as cocoa pod borer and pod rot, unproductive crops due to old age, low amount of fertilizer, and lack of attention to hygiene as well as the climate influence.

The possibility of increasing cocoa production at the agricultural level is still wide open and the various efforts include rejuvenating old or damaged cocoa plants, rehabilitation with side grafting, good cultivation technology, using superior clones, controlling pests and diseases, as well as intensifying production inputs [5-7]. According to [8], boosting cocoa planted area, production inputs and technical efficiency had positive effect to cocoa yield. Furthermore, the increase in cocoa productivity is followed by a rise in farmers' income [9], since most entrepreneurs are smallholders. Currently, there are few empirical studies on technical efficiency cocoa farming in Gorontalo. Therefore, this research aimed to measure the efficiency of cocoa farming in Pohuwato Regency Gorontalo along with its influencing factors. The information obtained is expected to be one of the considerations for improving agricultural efficiency in the Province.

\section{Research Methods}

\subsection{Research location and time}

The research was conducted in Pohuwato Regency, which is one of the cocoa production centers in Gorontalo Province. Also, the simple random sampling technique was adopted for the selection of respondents, and data were collected in December 2017.

\subsection{Data and sampling method}

Both primary and secondary data were used for analysis. The primary data, which include the socio-economic characteristics of farmers, and the input or output production as well as their respective prices were obtained from a survey of cocoa farmers selected by simple random sampling. Also, the secondary data were obtained from literature and related agencies to support the research.

\subsection{Data analyses}

The Cobb-Douglas Stochastic frontier production function was adopted to analyses the efficiency of cocoa farming production [10-12]. This frontier production function describes the maximum output that is achieved from each input [13]. Also, Cobb Douglas was adopted as the production function model, with several properties including homogeneity, simple form, ability to be transformed into a linear function, and the rarely caused problems, which is the most widely used [14]. The general form of the Cobb-Douglas production function model is as follows:

$$
Y=\beta 0 X 1 \beta 1 X 2 \beta 2 X 3 \beta 3 \ldots . X n \beta n \text { evi-ui }
$$

Where:

$\mathrm{Y}=$ the estimated production amount

$\beta_{0}=$ intercept

$\beta_{\mathrm{n}}=$ estimator parameter of the $\mathrm{i}$-th variable and is the elasticity

$\mathrm{X}_{\mathrm{i}}=$ the production factors used $(\mathrm{i}=1,2,3, \ldots, \mathrm{n})$

$\mathrm{e}=$ natural numbers $(2.718)$

vi-ui = error term (vi is noise effect, ui is a technical inefficiency effect of the model) 
However, the estimation of this equation will be easier when converted into a multiple linear form by logarithm equation. Therefore, the estimator equation model of the CobbDouglas frontier production function in cocoa farming is as follows:

$$
\ln Y=\ln \beta 0+\beta 1 \ln X 1+\beta 2 \ln X 2+\beta 3 \ln X 3+\beta 4 \ln X 4 \text { (vi-ui) }
$$

Where:

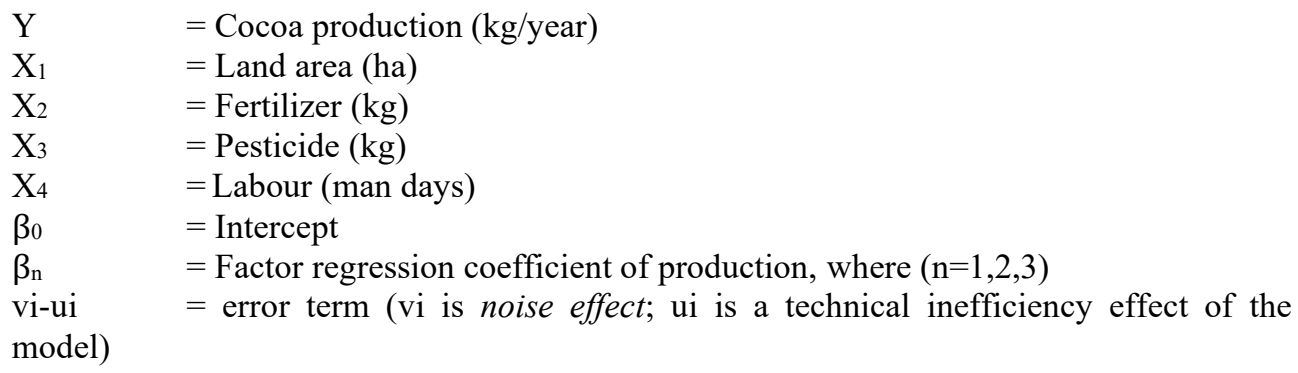

The expected coefficient values are $\beta_{1}, \beta_{2}, \beta_{3}$ and $\beta_{4}>0$, which implies that the coefficient value of the farming frontier production estimator function provides a positive predictive parameter value. Therefore, an increase in area, fertilizers, pesticides, and labour, amounts to a rise in cocoa production.

Furthermore, the stochastic frontier function provides two results simultaneously, these include the factors that affect technical efficiency and inefficiency cocoa farming. Furthermore, the technical efficiency (TE) of each i-th farmer on the production side is obtained by observing the stochastic frontier output. The formula used in measuring the TE analysis of cocoa farming is stated below:

$$
T E=E(Y * \mid u i, X 1, X 2, X 3, X 4) E(Y * \mid u i=0, X 1, X 2, X 3, X 4)
$$

Where:

TE $\quad=\mathrm{i}$-th farmer technical efficiency

$\mathrm{E}\left(\mathrm{Y}^{*} \mathrm{ui}, \mathrm{X}_{1}, \mathrm{X}_{2}, \mathrm{X}_{3}, \mathrm{X}_{4}\right)=$ observation output $(\mathrm{i}=1,2, . ., \mathrm{n})$

$\mathrm{E}\left(\mathrm{Y}^{*}\right.$ ui $\left.=0, \mathrm{X}_{1}, \mathrm{X}_{2}, \mathrm{X}_{3}, \mathrm{X}_{4}\right)=$ limit output $(\mathrm{i}=1,2, . ., \mathrm{n})$

The technical efficiency value lies between 0 and 1 inclusive $(0 \leq \mathrm{TE} \leq 1)$ This is inversely related to the value of technical inefficiency effect. Also, this is categorized as efficient when the value is $\geq 0.7$ and inefficient when it is $<0.7$. Furthermore, to determine the distribution parameter value (ui) of the technical inefficiency effect on cocoa farming, the following formula was used:

$$
u i=\delta_{0}+\delta_{1} Z_{1}+\delta_{2} Z_{2}+\delta_{3} Z_{3}+\delta_{4} Z_{4}
$$

Where:

ui $=$ technical inefficiency effects

$\delta_{0}=$ intercept or constant

$\mathrm{Z}_{1}=$ farmer age (years)

$\mathrm{Z}_{2}=$ education (years)

$Z_{3}=$ farming experience (years)

$Z_{4}=$ family member (person)

When the inefficiency estimator parameter is positive, then the variable has an effect on increasing business inefficiency. However, a negative value implies that the variable reduces the business inefficiency. 


\section{Result and Discussion}

\subsection{The characteristics of cocoa farmers}

The characteristics of cocoa farmers in Pohuwato Regency Gorontalo as displayed in Table 1 showed that they were at their productive ages with an average of 39.22 years. Meanwhile, the age range between the youngest and the oldest was 17-68 years. Moreover, previous research has shown that age is a source of production efficiency, that is, as farmers get older, their efficiency increases [11,15]. This is arguable since the increasing age adds to their experience in cocoa farming, therefore they have the knowledge to carry out good cultivation.

Furthermore, the average education level of farmers was 7.73 years, or at least they have completed basic education. Also, to increase farmers' knowledge in cocoa production, education, and some basic skills such as reading and analysis are important. The research $[11,15,16]$ conducted in Nigeria, Malaysia, and Ghana, respectively showed that farmers' education or knowledge has a positive correlation with production efficiency.

In addition, cocoa farmers had an average of 12.95 years of experience, the shortest and the longest at 1 and 37 years, respectively. Furthermore, farming experience enhances the efficiency of production since it increases knowledge as well as help to overcome obstacles such as pest and disease control.

Family, with an average of 4 members is one of the labour resources for cocoa farming and they perform several tasks such as fertilizing, pruning crops, controlling pests, harvesting, and drying cocoa beans.

Table 1. The characteristics of cocoa farmers in Pohuwato Regency, Gorontalo

\begin{tabular}{|l|c|c|c|c|}
\hline Item & Mean & $\begin{array}{c}\text { Standard } \\
\text { deviation }\end{array}$ & Minimum & Maximum \\
\hline Age (years) & 39.22 & 11.97 & 17.00 & 68.00 \\
\hline Education (years) & 7.73 & 2.68 & 6.00 & 16.00 \\
\hline Farming experience (years) & 12.95 & 7.11 & 1.00 & 37.00 \\
\hline $\begin{array}{l}\text { Number of family members } \\
\text { (person) }\end{array}$ & 4 & 1 & 1 & 7 \\
\hline
\end{tabular}

\subsection{Profits of Gorontalo cocoa farming}

The farmers' ultimate goal was to reach a high profit from the incurred costs. The profits reached by Gorontalo cocoa farmers are presented in Table 2.

Table 2. Revenue and costs of Pohuwato Regency cocoa farming

\begin{tabular}{|l|r|r|r|r|}
\hline \multicolumn{1}{|l|}{ Item } & \multicolumn{1}{c|}{ Total } & \multicolumn{1}{c|}{ Unit price } & \multicolumn{1}{c|}{ Value } & Percentage \\
\hline Revenue & 557 & 23,049 & $12,857,675$ & 100 \\
\hline Cocoa sales & \multicolumn{5}{|l|}{} \\
\hline Cost Input & 303 & 2,300 & 698,714 & 10.68 \\
\hline Phonska fertilizer (kg) & 97 & 1,800 & 174,890 & 2.67 \\
\hline Urea fertilizer (kg) & 13 & 120,591 & $1,632,012$ & 24.94 \\
\hline Pesticide (1) & 55 & 68,727 & $3,806,879$ & 58.17 \\
\hline Labour (man days) & & & 232,204 & 3.55 \\
\hline Depreciation of equipment & & & $\mathbf{6 , 5 4 4 , 6 9 9}$ & $\mathbf{1 0 0}$ \\
\hline Total cost & & & $\mathbf{6 , 3 1 2 , 9 7 6}$ & \\
\hline Profit & & & $\mathbf{1 . 9 6}$ & \\
\hline RC ratio & & &
\end{tabular}


Table 2 shows that the highest cost of cocoa farming was labour with $58.17 \%$, followed by pest control, and fertilizer. Also, labour is needed during fertilization, pruning, harvesting and post-harvest activities such as drying of the cocoa beans. Furthermore, there are two types of labour in cocoa farming, namely family and hired. Both are required when farmers lack sufficient time to complete work in their land, the hired workers are usually given a daily wage according to the number of days. The next cost requirement is pest and diseases control, this is important to ensure an increase in production. Furthermore, fertilizer is an important production input, and it is carried out to ensure the optimal growth and production of plants. The annual cost requirement includes labour of IDR 3.8 and 1.6 million for pesticide or insecticide as well as fertilizer of IDR 873 thousand.

The revenue obtained from this farming is the result of selling cocoa beans. The average annual income of cocoa farmers per hectare was IDR $12,857,675$ and when compared to the total costs incurred of IDR 6,544,699, the profit was IDR 6,312,679, which indicates that cocoa farming is profitable. Another indicator is the value of the RC ratio 1.9, which shows that every IDR 100 cost incurred will result in an income of IDR 196. Furthermore, research [17] reported that cocoa farming in Southeast Sulawesi generates an income of IDR. 7,160,900. Meanwhile, [18] estimated that cocoa farmers in Taluditi, Gorontalo earns profit between IDR 5,643,420 and IDR 8,213,137 per year.

\subsection{The Effect of Production Inputs towards cocoa production and efficiency}

The production function of cocoa was estimated using the stochastic frontier Cobb Douglas. It was then analyzed using two methods which include Ordinary Least Square (OLS) and Maximum Likelihood Estimation (MLE). The OLS provides an overview of the average performance of cocoa production at the existing technology level. It also determines the violation of the assumption by the model (multicollinearity, autocorrelation, heteroscedasticity). Meanwhile, the MLE method describes the maximum production output that is achieved using the existing input factors. The production function model of the Douglas Cobb using the OLS method is shown in Table 3.

Table 3. The estimation model of the stochastic frontier Cobb Douglas cocoa production function using the OLS method

\begin{tabular}{|l|c|c|c|c|}
\hline Variable & Coefficient & t-value & Pr $>|\mathbf{t}|$ & VIF \\
\hline Constant & 7.099 & 5.519 & 0.000 & \\
Land area & $1.166^{* * *}$ & 7.980 & 0.000 & 1.877 \\
Fertilizer & -0.021 & -0.747 & 0.459 & 1.450 \\
Pesticide & 0.024 & 0.874 & 0.387 & 1.330 \\
Labour & 0.180 & 1.198 & 0.237 & 2.013 \\
Farmer Age & -0.532 & -1.565 & 0.124 & 1.345 \\
Education & 0.116 & 0.512 & 0.611 & 1.266 \\
Family members & 0.045 & 0.183 & 0.856 & 1.217 \\
\hline R-Square & 0.746 & & & \\
F-value & 19.692 & & & \\
Durbin-Watson & 1.902 & & & \\
\hline
\end{tabular}

Description: *** significant at $\alpha 0.01$

Table 3 showed an R-square value of $74.6 \%$, which implies that the input variations explain the differences in cocoa production by $74.6 \%$, and the remaining $25.4 \%$ is explained by other factors outside the model. Furthermore, to determine the inequality of variance from the residuals of one observation to another, the variance inflation factor (VIF) value is observed. A VIF value below 10 indicates that the model does not experience heteroscedasticity. Also, the autocorrelation symptom was detected by 
examining the Durbin-Watson value of 1.902 , the $\mathrm{dL}=1.253$, and $\mathrm{dU}=1.909$. Therefore, it is concluded that the model does not have autocorrelation symptoms since the DurbinWatson value is greater than the $\mathrm{dL}$ (1.253) and smaller than the dU (1.909). Furthermore, the relationship between input factors and cocoa production results is illustrated by the Fvalue and $p$-value. The p-value $<0.01$ means that the F-value is significant at a $99 \%$ confidence level, that is, the production input factors jointly affect cocoa production. Based on the t-test, which explains the effect of individual independent variables on the dependent, it is known that land area have a significant and positive effect on cocoa production output with a $99 \%$ confidence level. Similarly, previous studies argued that land area had a significant and positive effect on cocoa production [19, 12, and 17]. The next step is to estimate the stochastic frontier cocoa production model using the MLE method (Table 4)

Table 4. The estimation model of the stochastic frontier Cobb Douglas cocoa production function using the MLE method

\begin{tabular}{|l|c|c|}
\hline Variable & Coefficient & t-ratio \\
\hline Constant & 6.426 & 75.64 \\
Land area & $1.028^{* * *}$ & 153.1 \\
Fertilizer & $0.018^{* *}$ & 2.282 \\
Pesticide & $0.066^{* * *}$ & 15.32 \\
Labour & $0.084^{* * *}$ & 7.025 \\
\hline Sigma-Square & 0.907 & \\
Gamma & 0.999 & \\
Log-likehood function OLS & -52.917 & \\
Log-likehood function MLE & -42.204 & \\
LR test & 21.425 & \\
\hline
\end{tabular}

Description: *** significant at $\alpha 0.01 ; * *$ significant at $\alpha 0.5$

The Cobb Douglas production function model with the MLE method is presented in Table 4. The results of the MLE log-likelihood function are greater than the OLS, which means that the model is good. The variance (sigma-square) of the model was 0.907, therefore the error term ( $\mu$ i) is normally distributed. Also, the gamma $(\gamma)$ value of 0.999 , implies that $99.9 \%$ of the error term in the production function is caused by the farmers' inefficiency and the rest is influenced by other factors such as climate and weather [8]. Meanwhile, the generalized likelihood ratio shows a value of 21,425 , which is greater than the Kodde and Palm $\alpha$ table value of $1 \%(12,483)$. This means that the cocoa production function is influenced by the efficiency and technical inefficiency of cocoa farmers.

Based on the t-test, it was concluded that all production inputs in the model had a significant and positive effect on cocoa production at a $99 \%$ confidence level. However, the input factor with the highest effect is the land area with a coefficient value of 1.028 , therefore an additional land area of $100 \%$ will increase production by $102.8 \%$. Meanwhile, the effect of other production input factors is smaller than the land area. Furthermore, a $100 \%$ rise in fertilizer, insecticide, and labor units will be followed by an increased output of $1.8 \%, 6.6 \%$, and $8.4 \%$, respectively. This research is consistent with others conducted in Nigeria and Central Sulawesi, which proved that land area is a leveraging factor in increasing the cocoa production efficiency, apart from being affected by fertilizers, pesticides, and labor $[11,20]$. 


\subsection{The distribution of technical efficiency}

Table 5 shows that most cocoa farmers $(72.73 \%)$ are not technically competent, and this is seen from the efficiency level below 0.7 . Consequently, only a small proportion of farmers $(27.27 \%)$ have achieved efficiency values above 0.7 . Furthermore, the average value of the cocoa farmers efficiency was 0.52 , which is inefficient. In conclusion, by considering the input factor, farmers are able to increase their production efficiency by $48 \%$. Also, research [12] concluded that production efficiency is improved with the use of appropriate inputs and good farm management.

Table 5. The distribution of technical efficiency

\begin{tabular}{|l|c|c|}
\hline Efficiency scores & Number of farmers & Percentage \\
\hline $0.7<$ & 40 & 27.27 \\
$\geq 0.7$ & 15 & 72.73 \\
\hline Total & 55 & 100.00 \\
Mean & 0.52 & \\
Minimum & 0.045 & \\
Maximum & 0.999 & \\
\hline
\end{tabular}

\subsection{Source of inefficiency in cocoa production}

The inefficiency source in cocoa farming was analyzed using the stochastic frontier production model. The results are shown in Table 6.

Table 6. Estimation model of the technical inefficiency stochastic frontier production function

\begin{tabular}{|l|c|c|}
\hline Variable & Coefficient & t-ratio \\
\hline Constant & -0.791 & -0.746 \\
Age & $0.471^{*}$ & 1.521 \\
Education & -0.152 & -0.371 \\
Number of familiy members & -0.380 & -0.914 \\
\hline Sigma-Square & 0.907 & \\
Gamma & 0.999 & \\
Log-likehood function OLS & -52.917 & \\
Log-likehood function MLE & -42.204 & \\
LR test & 21.425 & \\
\hline
\end{tabular}

Description: significant at $\alpha 0.1$

Table 6 shows that farmers' age has a positive and significant relationship to the inefficiency of cocoa production at a $90 \%$ confidence level. This means that the older the farmer, the less efficient in producing cocoa. Furthermore, inefficient production by old farmers is caused by several factors, such as the ability to manage their gardens due to old age, or they usually have other businesses when they get older such as farming maize, rice, horticulture, livestock, and others. This result in mismanagement of farming activities and therefore result in inefficient production. Furthermore, the positive correlation of farmers' age with inefficiency is consistent with other studies [11, 21, 15 and 12] however, it contradicts research [7]. This is different from the other factors, although not significant, that cocoa production will be more efficient when education and the number of family members increase. Also, the negative correlation of education with inefficiency is in accordance with research [15]. Meanwhile, the negative correlation between the number of family members and inefficiency is in accordance with studies $[11,16]$. 


\section{Conclusion}

The research showed that cocoa farmers had a profit of IDR 6,312,679, which may be increased through efficient production. This is because cocoa production in Pohuwato is still inefficient with a value of 0.52 . Therefore, it requires to increase cocoa farming efficiency by increasing farmers' access to production inputs such as fertilizers and pesticides, and improving the management of cocoa cultivation.

\section{References}

1. Ministry of Agriculture, Tree crop estate statistics of Indonesia 2018-2020 (Ministry of Agriculture, Jakarta, 2019).

2. BPS-Statistics Indonesia, Indonesian cocoa statistics (BPS-Statistics Indonesia, Jakarta, 2019).

3. BPS-Statistics Indonesia, Results of inter-censal agricultural survey 2018 (BPSStatistics Indonesia, 2019).

4. Ministry of Agriculture, Tree crop estate statistics of Indonesia 2012-2014 (Ministry of Agriculture, Jakarta, 2013).

5. A. Tothmihaly, V. Ingram, S. von Cramon-Taubadel, Ecol. Econ. 158, 134-145 (2019).

6. Rubiyo, Siswanto, J. Ind. Beverage Crop. 3, 33-48 (2012).

7. D. Asri, A. Rifin, W. B. Priatna, J. AGRISEP. 18, 75-88 (2019).

8. J. A. Onumah, E. E. Onumah, R. M. Al-Hassan, B. Brümmer, Agric. Econ. 59, 271280 (2013).

9. V. J. Ingram, A. Tothmihaly, Agribusiness. 1, 1-18 (2018).

10. 10. A. A. Rouf, S. Munawaroh, J. Pengkaj. dan Pengemb. Teknol. Pertan. 19, 103 (2016).

11. Agom, D. Ila, S. Ben Ohen, K. O. Itam, N. N. Inyang, Int. J. Agric. Manag. Dev. 2, 177-185 (2012).

12. J. Sumarno, R. H. Anasiru, E. Retnawati, Inform. Pertan. 27, 73-86 (2018).

13. C.-M. Chen, D. M. A, B. Lieberman, Strateg. Manag. J. 36, 19-36 (2015).

14. D. L. Debertin, Agricultural Production Economics (Macmillan Publishing Company, New Jersey, 2012).

15. W. R. Fadzim, M. Izraf, A. Aziz, A. Zafarullah, A. Jalil, Int. J. Supply Chain Manag. 6, 254-258 (2017).

16. G. Danso-Abbeam, L. J. S. Baiyegunhi, T. O. Ojo, Heliyon. 6, 1-11 (2020).

17. Rusdin, Z. Abidin, Mega Akt. 7, 72-80 (2018).

18. Masni, Y. Boekoesoe, Y. Saleh, Agrinesia. 1, 16-23 (2016).

19. I. Alkamalia, Mawardati, S. Budi, Agrifo. 2, 56-61 (2017).

20. Effendy, M. Fardhal Pratama, R. A. Rauf, M. Antara, M. Basir-Cyio, Mahfudz, Muhardi, PLoS One. 14, 1-15 (2019).

21. O. A. Popoola, G. O. Ogunsola, K. K. Salman, Int. J. Agric. Food Res. 4, 1-14 (2015). 